\title{
De Winter pattern: a forgotten pattern of acute LAD artery occlusion
}

\author{
Mafalda Carrington, Ana Rita Santos, Bruno Cordeiro Picarra, João António Pais
}

Department of Cardiology, Hospital do Espirito Santo EPE, Evora, Portugal

Correspondence to Dr Mafalda Carrington, mafaldacarrington@gmail.com

Accepted 13 October 2018

\section{DESCRIPTION}

The De Winter ECG pattern was reported as an indicator of acute left anterior descending (LAD) coronary artery occlusion and is considered an anterior ST-elevation myocardial infarction (STEMI) equivalent. ${ }^{1}$ The key diagnostic features include ST-depression and peaked T-waves in precordial leads, and it can be seen in around $2 \%$ of patients with anterior myocardial infarction. ${ }^{12}$

We report a case of a 77-year-old woman with history of treated hypertension and hypercholesterolaemia. She presented to the emergency department with a typical acute chest pain, almost 1 hour after symptom onset. An ECG was immediately obtained and revealed sinus bradycardia at 45 bpm, with 1-2 mm ST-depression at the J point that continued into a wide, tall, positive, symmetrical T-wave in leads V2-V6, and a $0.5 \mathrm{~mm}$ ST-elevation in lead aVR (figure 1A). She was immediately transferred to our primary coronary intervention (PCI) centre. The ECG monitoring on arrival at the catheterization laboratory displayed persistent ST-depression and tall T-waves in precordial leads. Coronary angiography showed a culprit lesion in the proximal LAD artery, which was occluded (TIMI-0 flow) (figure 2). The remaining coronary arteries exhibited non-significant disease. Primary PCI of the proximal LAD artery was performed $145 \mathrm{~min}$ after STEMI diagnosis. A drug-eluting stent was implanted with good clinical and angiographic result (TIMI-3 flow).

Troponin I level on admission was $0.07 \mathrm{ng} / \mathrm{mL}$ (normal range $<0.12 \mathrm{ng} / \mathrm{mL}$ ), and a maximum value of $34.9 \mathrm{ng} / \mathrm{mL}$ was observed approximately 24 hours after primary angioplasty. Potassium levels on admission were normal $(4.5 \mathrm{mmol} / \mathrm{L})$. The echocardiogram performed revealed a moderate-to-severe depression in left ventricle function due to

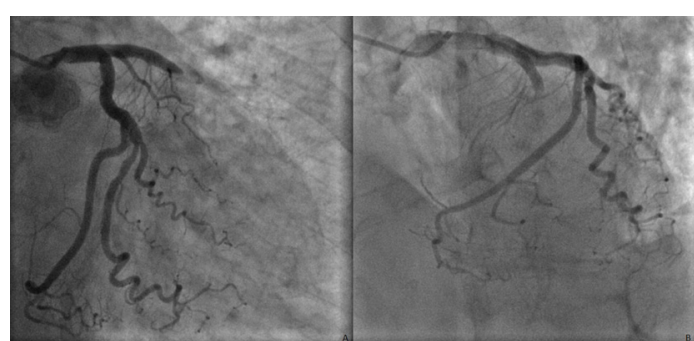

Figure 2 Proximal left anterior descending coronary artery occlusion in oblique anterior right caudal (A) and left cranial (B) views.

hypokinesia of the anterior left wall and apical segments of the remaining walls, with an appearing ventricular aneurysm. Electrocardiographic evolution showed sinus rhythm at $90 \mathrm{bpm}$, with Q-waves, downsloping ST-elevation and T-wave inversion in leads V2-V4, and Q-waves in inferior leads (II, III, $\mathrm{aVF}$ ) (figure 1B).

We present a case of a patient with acute chest pain and an ECG with a De Winter pattern that was associated with acute proximal LAD artery occlusion despite the lack of ST-elevation. According to a systematic review published in $2017,{ }^{3}$ De Winter pattern has a high positive predictive value $(95.2 \%$ $100 \%)$ for acute occlusion of LAD artery. The De Winter pattern may be confused with hyperacute T-waves, which may occur in the context of hyperkalaemia, but also as a manifestation of early ischaemia, displaying very tall T-waves, with a broader base, and preceded by ST-segment elevation. Unlike the static De Winter pattern that generally lasts from first medical contact to primary PCI, hyperacute T-waves occur within seconds after total occlusion of a coronary artery and usually resolve within minutes. $^{2}$
Check for updates

(C) BMJ Publishing Group Limited 2018. No commercial re-use. See rights and permissions. Published by BMJ.

\begin{tabular}{l} 
To cite: Carrington M, \\
Santos AR, Picarra BC, et al. \\
BMJ Case Rep Published \\
Online First: [please \\
include Day Month Year]. \\
doi:10.1136/bcr-2018- \\
226413 \\
\hline
\end{tabular}
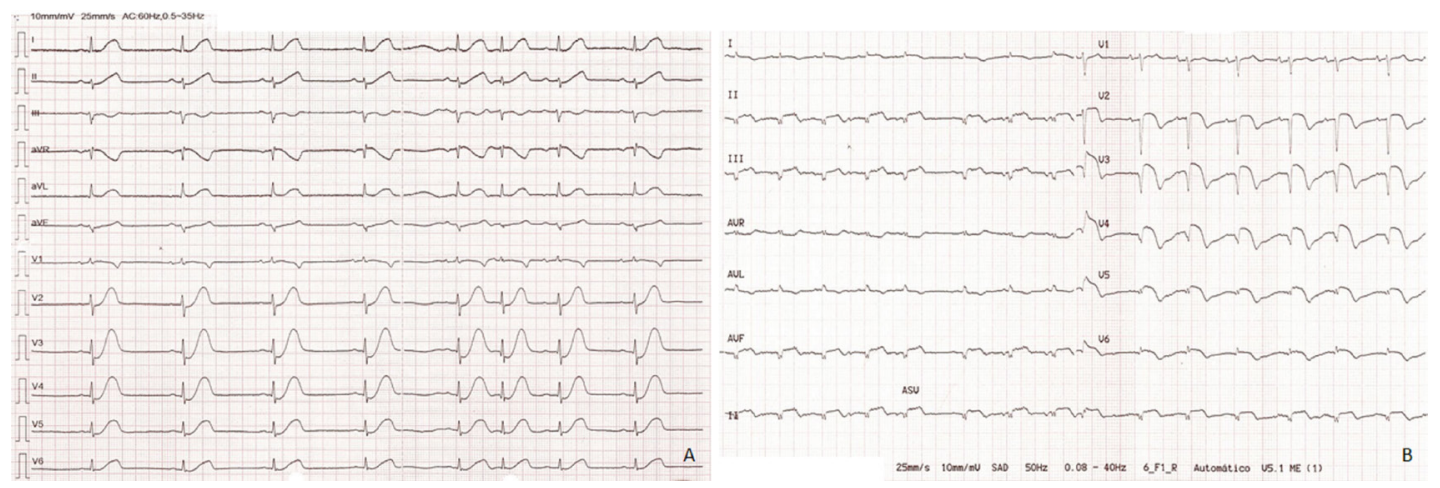

Figure 1 (A) De Winter ECG pattern in a patient presenting with acute chest pain. (B) ECG after successful angioplasty of left anterior descending (LAD) artery. 


\section{Learning points}

- The De Winter ECG pattern typically displays tall T-waves, but the static nature and characteristic ST-depression differentiates this pattern from hyperacute T-waves.

- The De Winter ECG pattern and the Wellens' syndrome should prompt the suspicion of a proximal left anterior descending occlusion, as both are considered anterior ST-elevation myocardial infarction equivalents.

- The immediate recognition of these ECG changes is essential for referring patients to urgent reperfusion therapy and may have important prognostic implications.

The Wellens' syndrome is another example of an unrecognised high-risk presentation of anterior ischaemia, and it is characterised by deeply inverted or biphasic $\mathrm{T}$ waves in multiple precordial leads.

In conclusion, missing these high-risk ECG patterns as reversible severe ischaemia may lead to undertreatment of patients with a STEMI, and implies negative effects on morbidity and mortality.

Acknowledgements We acknowledge the support given by Dr. José Aguiar, head of Cardiology department, and we thank all the practitioners in the department that contributed to the fast resolution of the case.

Contributors JAP and BCP conducted a literature review, MC wrote the case and ARS selected the angiography images. All the authors reviewed the case description.

Funding The authors have not declared a specific grant for this research from any funding agency in the public, commercial or not-for-profit sectors.

Competing interests None declared.

Patient consent Obtained.

Provenance and peer review Not commissioned; externally peer reviewed.

\section{REFERENCES}

1 de Winter RJ, Verouden NJ, Wellens HJ, et al. A new ECG sign of proximal LAD occlusion. N Engl J Med 2008;359:2071-3.

2 Verouden NJ, Koch KT, Peters RJ, et al. Persistent precordial "hyperacute" T-waves signify proximal left anterior descending artery occlusion. Heart 2009;95:1701-6.

3 Morris NP, Body R. The De Winter ECG pattern: morphology and accuracy for diagnosing acute coronary occlusion: systematic review. Eur J Emerg Med 2017;24:236-42.

Copyright 2018 BMJ Publishing Group. All rights reserved. For permission to reuse any of this content visit

http://group.bmj.com/group/rights-licensing/permissions.

BMJ Case Report Fellows may re-use this article for personal use and teaching without any further permission.

Become a Fellow of BMJ Case Reports today and you can:

- Submit as many cases as you like

- Enjoy fast sympathetic peer review and rapid publication of accepted articles

- Access all the published articles

- Re-use any of the published material for personal use and teaching without further permission

For information on Institutional Fellowships contact consortiasales@bmjgroup.com

Visit casereports.bmj.com for more articles like this and to become a Fellow 